\title{
EARTH'S CREATION STIMULUS: CREATION OF GRAPHIC ARTS WITH USED PLYWOOD MEDIA
}

\author{
Sigit Purnomo Adi ${ }^{1}$, Pande Made Sukerta ${ }^{2}$, M. Dwi Marianto ${ }^{3}$, and Sri Hadi ${ }^{4}$ \\ ${ }^{1}$ Universitas Sebelas Maret Surakarta, Indonesia \\ ${ }^{2}$ Institut Seni Indonesia (ISI) Surakarta, Indonesia \\ ${ }^{3}$ Institut Seni Indonesia (ISI) Yogyakarta, Indonesia \\ ${ }^{4}$ Institut Seni Indonesia (ISI) Surakarta, Indonesia \\ E-mail correspondence: sigitpurnomoadi@staff.uns.ac.id
}

\begin{abstract}
Natural phenomena, especially climate change, are increasingly worrying lately. Graphic art can be used to express concern for the environment in response to climate change. The creation of this graphic art work uses the concept of the earth's creation stimulus. The creative methods used include: experimentation, contemplation, and formation. Abstract Expressionism was chosen as the style of personal expression in the creation of this work. The creative technique used is high printing technique with used plywood media. The results of the creation process show that the visualization of the concept of the earth's creative stimulus produces the forms of circles and lines. These forms are the main motif in the creation of graphic art with the stimulation of this earth's creativity
\end{abstract}

Keywords: High print, creative stimulation, and graphic arts.

\begin{abstract}
ABSTRAK
Fenomena alam khususnya perubahan iklim semakin mengkhawatirkan akhir-akhir ini. Seni grafis dapat digunakan untuk mengekspresikan kepedulian terhadap lingkungan dalam rangka merespon perubahan iklim tersebut. Penciptaan karya seni grafis ini menggunakan konsep rangsang cipta bumi. Metode kreasi yang digunakan, meliputi: eksperimen, perenungan, dan pembentukan. Aliran Abstrak Ekspresionisme dipilih sebagai gaya ekspresi personal dalam penciptaan karya ini. Adapun teknik kreasi yang digunakan adalah teknik cetak tinggi dengan media triplek bekas. Hasil dari proses kreasi menunjukkan bahwa visualisasi terhadap konsep rangsang cipta bumi menghasilkan bentuk-bentuk lingkaran dan garis. Bentuk itu menjadi motif pokok dalam penciptaan seni grafis dengan rangsang cipta bumi ini.
\end{abstract}

Kata kunci: Cetak tinggi, rangsang cipta, dan seni grafis.

\section{Introduction}

This article is a creative and innovative design that uses the concept of artistic creation as a personal expression by using the "abstract expressionism" model. The 


\section{Artistic}

visual form of this work is a work of graphic art that begins with a creative stimulus to the earth.

The artistic creation of this graphic art was inspired by the concept of Hastagina, especially the number $8+1$. The creation of this work focuses on high

printing techniques using used plywood media. The inspiration from traditional art is applied to contemporary mediums. There are two different aspects to the world of art. Some have a traditional nature, which leads to tradition, even though art desires something creation and innovation, even novelty or more so called modern art (Adi, 2017).

The earth we walk on is indeed old. Earth has provided welfare for mankind and other living things. Earth must be preserved at all times. There are many ways to preserve the earth we love. One of which is as a graphic artist by creating graphic art by taking the earth's creative stimulus as a foothold and collaborating with modern art, especially abstract expressionism. This combination is one of the strategies so that artists, especially graphic artists, have a contribution in preserving the earth we love. Earth is very vital role in the life of humans and other living things where they are. Environmental management has been handed over to mankind because Allah SWT has created humans from the earth (soil) and made them human to prosper on all fronts (Ilyas, 2008).

In the life of the Javanese people to get true perfection is known as the Hastagina teachings $(8+1)$. To get this, Javanese people must be able to control themselves against the 4 lusts that surround them. The meaning of color in Hastagina has similarities with other Javanese philosophy, namely Keblat Papat Lima Pancer. Those two Javanese philosophies have long been embedded in Javanese society as a philosophy that is held until today (Kartika, 2016).

The creation of this graphic art uses an artistic creation process, which includes experimentation, contemplation, and formation (art structure). The main object in this work comes from the stimulus of the earth's creativity and then it is processed in such a way so that it becomes a graphic art work with high printing techniques, used 
plywood media, and abstract expressionism techniques.

\section{Literature Review}

\subsection{Abstract Expresionism}

Abstract Expressionism was a painting movement that boomed in the 1950s, and the movement was pioneered by the New York School consisting of Jackson Pollock, Franz Kline, Mark Rothko and Willem de Kooning (Thorne, 2019). Abstract Expressionism belongs to the flow of painting and can be defined as an attempt to visualize works of art with lines and colors that tend to be nongeometric. There are two types that are included as Abstract Expressionism flow, including "color field painting", the lines and colors expressed tend to display bursts, plots, and expressive forms on canvas (Kartika, 2004). Abstract Expressionism is growing rapidly in various countries and most popular in the United States.
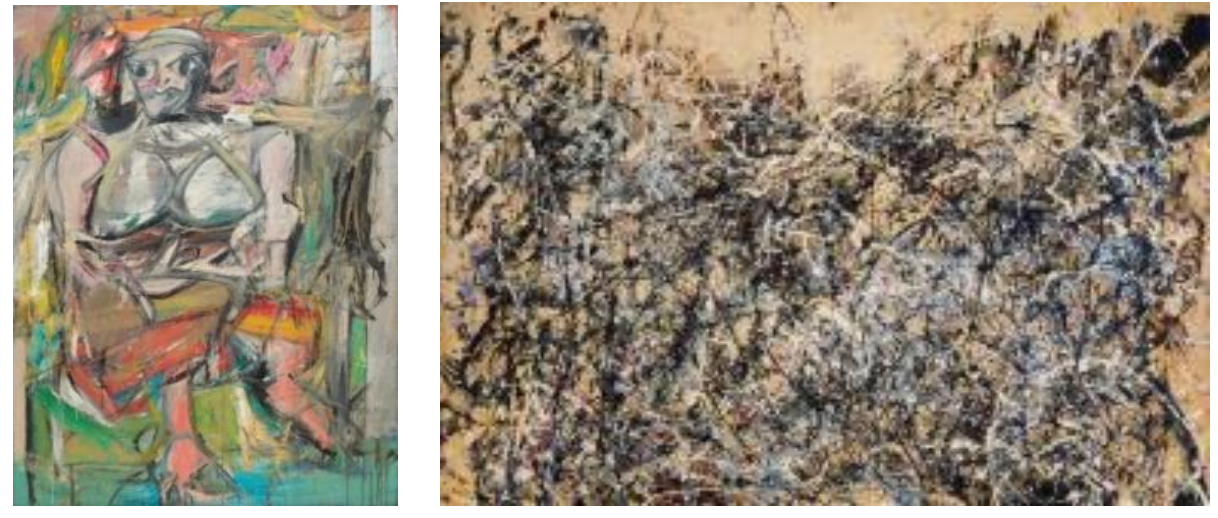

Figure 1. "Woman" painting by Willem de Kooning (left)

(Source: https://www.moma.org/collection/works/79810, 8 June 2020, 12.00 AM)

Figure 2. Painting by Jackson Pollock (right)

(Source: https://www.britannica.com /biography/Jackson-Pollock/Poured, 3 June 2021, 07.32 PM)

Some of the artworks that are used as references in the creation of this graphic art are works by Willem de Kooning and Jackson Pollock. Willem De Kooning, a painter from the Netherlands, is very creative and homage to Abstract Expressionism. His work entitled "Woman" is a work of art with a strong character. 


\section{Artistic}

The author is attracted to Willem De Kooning's very expressive style, but the author has a different style, because it uses graphic art techniques.

The second artist is Jackson Pollock, a painter from the United States. He is a figure of abstract expressionism. The author is attracted by Willem De Kooning's very expressive style. His style is an inspiration for the author, but the work of the author produces has a difference, because it uses graphic art techniques.

\subsection{Graphic Arts}

Graphic art is created through a manual printing process using materials and most importantly duplicating the work (Susanto, 2011). There are many techniques in graphic arts, one technique that is phenomenal and well known among students, artists, and the public is high printing. This technique has special features in visual form that is difficult to imitate with other techniques (Adi, 2020).

Monroe Beardsley explains 3 steps to be able to create beauty from objects that have aesthetic value, namely: Unity, Complexity, and Intensity (Kartika, 2020). Meanwhile, the media and activities of eco-art practitioners are diverse, covering various jobs in the fields of painting, photography, video, performance art, architecture, sculpture, installation and other fields (Marianto, 2017), graphic arts can also be used as a medium of expression for eco-art.

\subsection{Javanese Philosophy}

This graphic art creation uses Javanese teachings as a philosophical reference. Javanese people recognize the system of time in the cosmos, which is an inseparable relationship between themselves and the universe. This view is known by the Javanese as keblat papat lima pancer, in Javanese cosmogony; earth (land) is symbolized in black with the north showing the lust of lauwamah (Simuh, 2019). Javanese people cannot be separated from the environment (nature).

For the Kejawen (adhering to the Javanese belief), that humans come from 4 elements that are physical and spiritual or supernatural souls given by God. The four elements according to the Javanese as Sedulur Papat (Four Brothers). Soil with black 
color (dark character) is an element that forms aluamah lust, humans have the instinct to eat and drink to be used as energy in their lives. From this energy, humans can carry on their lives and actively carry out activities (Achmad, 2019). Javanese belief teaches where humans come from and where they will return.

The Javanese community in their searching to find true perfection is known as the "Hastagina" teaching $(8+1)$ (Kartika, 2016). The color symbolism used in the Hastagina teaching has the same basis as the symbolism in Javanese Cosmogony "keblat papat lima pancer" (4+1). Javanese life rites use these teachings, for example to determine matchmaking, determine good days for marriage, determine good days for traveling, hunting, or cutting down trees, and so on.

\subsection{Earth and Environment}

Environmental problems are essentially the relationship between humans and their environment, and environmental problems can be referred to as ecological problems. Ecological problems really need to be solved together, considering that the earth and our environment are getting damaged (Soemarwoto, 1997). Artists as members of society and inhabitants of the earth have a role in helping prevent damage to the natural environment.

The earth has undergone significant changes with high concentrations of greenhouse gases that can raise the temperature on earth, thus making the earth uncomfortable. In addition, the melting of ice at the Earth's poles endangers cities on the coast, household waste and other wastes (Irwan, 2020). Various efforts have been made to support the sustainability of the earth and the environment so that it is maintained.

\section{Creation Methodology}

This creation uses emic and ethical data. The data used by an artist for the artistic creative process, including experimentation, contemplation, and formation. The process of experimentation carried out by artists/designers in the process of artistic creation, among others: (1) experimenting with several alternatives in 


\section{Artistic}

creating works adapted to the expression of the artist/designer, (2) experimenting with several alternative techniques according to the expression of the artist/designer, ( 3 ) experimenting with several alternative tools and media adapted to the expression of the artist/designer, and (4) selecting a visual concept or layout (Kartika, 2016).

In the Experimental stage, the author uses a high printing technique with used plywood media. The choice of this technique is because high printing techniques can be combined with any media, for example used paper materials, used $\mathrm{MMT}^{1}$, etc. The materials and tools used are oil-based ink, rubber ink rolls, chopping tools, and used plywood. The contemplation stage is carried out through inner research, where the author uses prayer and meditation to find the shape of circles and lines which later become the main motifs in the creation of this graphic art. And, the Formation stage is carried out with a layout design, so that the resulting work has a high aesthetic value.

\section{Discussion}

\subsection{Creative Process}

1). The Concept of Stimulating the Creation of the Earth

The author uses the concept of personal expression with an abstract expressionism model, especially the stimulation of the earth's creativity with the layout. The reason for choosing Abstract Expressionism is because the author really enjoys working with expressiveness. This graphic art work is used as a symbol of the author's personal expression, so that the resulting works are in accordance with the author's perception.

\section{2). Visualization of Earth's Creation Stimulus}

The visualization of the work produced with the concept of the earth's creative stimulus is very much in accordance with the writer's inner research which produces the forms of circles and lines. These forms are the main motifs in the creation of this graphic art and are included in the Abstract Expressionism flow. The use of used

\footnotetext{
${ }^{1}$ MMT is an abbreviation of Printer Metromedia Technologies, this term is commonly used to refer to publication media that are printed from plastic materials
} 
plywood as a reference is a form of the artist's concern for the problems of the natural environment. The earth must be protected from various pollutants, so that the earth will be good from time to time.

\subsection{Artwork Description}

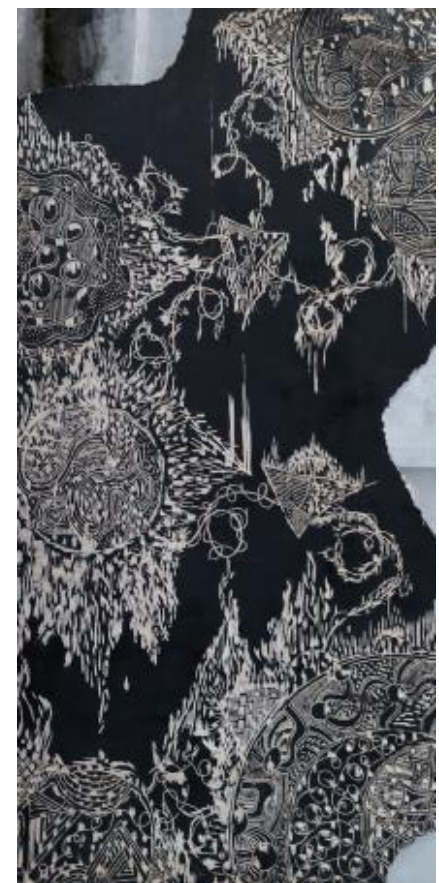

Figure 3. "Buwono Alit", 255x155 cm, woodcut on paper, 2/3 edition.

(Creator: Sigit Purnomo Adi, 2021)

The graphic art work entitled "Buwono Alit" also means the little universe (microcosm). This work which is a personal expression is a visualization of the concept of earth stimulation. This work describes the buwono alit or little universe (microcosm) which means human. Humans as caliphs on this earth must be able to control themselves to be able to achieve kasampurnaan sejati (true perfection). This work uses plywood as a form of concern for the love of the earth.

The graphic art work entitled "Buwono Ageng" can be interpreted as the jagat gedhe (big universe) or the macrocosm. This work expresses personally about the concept of earth stimulation. This work describes the buwono ageng or jagat gedhe (macrocosm) which means the universe. Humans must protect the universe from 


\section{Artistic}

being damaged by controlling themselves. Self-control can lead to the path to kesampurnaan sejati (true perfection). This work was created with used plywood as a form of concern for the love of the earth.

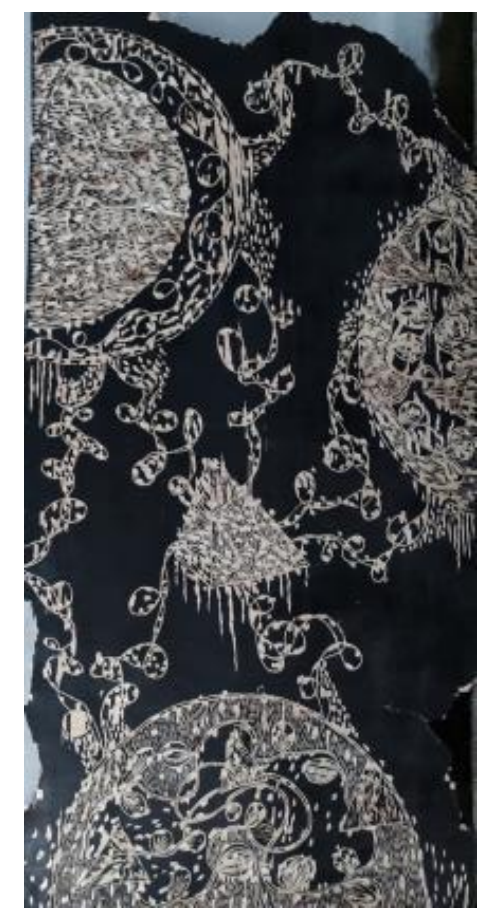

Figure 4. "Buwono Ageng", 255x155 cm, woodcut on paper, $2 / 3$ edition.

(Creator: Sigit Purnomo Adi, 2021)

\section{Conclusion}

The creation of this graphic art uses the Javanese philosophy of searching for true perfection, known as the "Hastagina" teaching $(8+1)$. The type of flow chosen in this creation is abstract expressionism. The model is considered relevant for the application of the concept of personal expression, especially the stimulation of creativity to the earth with the layout. With the Abstract Expressionism model, the author really enjoys creative activities with expressiveness.

The form of visualization of graphic art works with the concept of stimulating the creation of the earth is very much in accordance with the writer's inner research, which produces the shapes of circles and lines. This form is the main motif in the creation of graphic art with the stimulation of this earth's creativity. The use of 
materials consisting of used plywood as a reference is a form of the artist's concern in addressing environmental problems. The earth and everything in it must be maintained so that it is sustainable for future generations.

\section{References}

Achmad, S. W. (2019). Sejarah Agama Jawa Menelusuri Kejawen sebagai Subkultur Agama Jawa. Yogyakarta: Araska.

Adi, S. P. (2017). Perkembangan Seni Urban di Surakarta. Surakarta: UNS Press.

Adi, S. P. (2020). Cetak Grafis dan Pengaplikasiannya. Surakarta: UNS Press.

Ilyas, M. (2008). Lingkungan Hidup dalam Pandangan Islam. Jurnal Sosial Humaniora, 1(2), 154-166. doi: https://doi.org/10.12962/j24433527.v1i2.672

Irwan, Z. D. (2020). Lanskap Hutan Kota Berbasis Kearifan Lokal. Jakarta: Bumi Aksara.

Kartika, D. S. (2004). Seni Rupa Modern. Bandung: Rekayasa Sains.

Kartika, D. S. (2016). Kreasi Artistik: Perjumpaan Tradisi Modern dalam Paradigma Kekaryaan Seni. Karanganyar: Citra Sains LPKBN.

Kartika, D. S. (2020). Kritik Seni. Karanganyar: LPKBN: Citra Sain.

Marianto, M. D. (2017). Seni dan Daya Hidup dalam Perspektif Quantum. Yogyakarta: Scritto Books dan BP ISI Yogyakarta.

Simuh. (2019). Mistik Islam Kejawen Raden Ngabehi Ranggawarsita. Suatu Studi terhadap Wirit Hidayat Jati. Jakarta: Penerbit Universitas Indonesia (UIPress).

Soemarwoto, O. (1997). Ekologi Lingkungan Hidup dan Pembangunan. Jakarta: Djambatan.

Susanto, M. (2011). Diksi Rupa: Kumpulan Istilah dan Gerakan Seni Rupa. Yogyakarta: DictiArt Lab.

\section{ARTISTIC : International Journal of Creation and Innovation}

Publisher:

Program Pascasarjana

Institut Seni Indonesia (ISI) Surakarta

Available online at:

https://jurnal.isi-ska.ac.id/index.php/artistic

How to Cite:

Adi, Sigit Purnomo, et.all. (2021). Earth's Creation Stimulus: Creation of Graphic Arts with Used Plywood Media.

ARTISTIC : International Journal of Creation and Innovation, 2(1), 33-41 